\title{
The Protective Effect of Curcumin Against Gentamicin-Induced Renal Dysfunction and Oxidative Stress in Male Albino Rats
}

\author{
Bushra H. El-Zawahry and Effat M. Abu El Kheir* \\ Physiology and Biochemistry*Departments \\ Faculty of Medicine Al -Azhar University-Cairo
}

\begin{abstract}
Background: Generation of free radicals in the renal cortex plays an important role in the pathogenesis of gentamicin-induced nephrotoxicity. Curcumin, the yellow curry pigment isolated from turmeric, has been confirmed to have a strong antioxidant and free radical scavenging actions. In the present study, we investigated the possible protective effect of curcumin against gentamicin-induced nephropathy in male albino rats.

Methods: Thirty two male albino rats were divided into 4 equal groups (Gr.): (Gr.I) control, injected i.p with $1 \mathrm{cc}$ isotonic saline solution/day for 8 wks; (Gr.II) received 200 $\mathrm{mg} / \mathrm{kg} /$ day curcumin (Cur. ) orally, suspended in normal saline, for 8 wks ; (Gr.III) injected I.p by $100 \mathrm{mg} / \mathrm{kg} /$ day gentamicin (Gen.) for 8 days followed by $1 \mathrm{cc}$ saline I.p thereafter; (Gr.IV) (Cur./Gen.) received $200 \mathrm{mg} / \mathrm{kg} / \mathrm{day}$ Cur. for one week before starting Gen injection (100 $\mathrm{mg} / \mathrm{kg} /$ day) for 8 days during which Cur. was received concurrently with Gen then Cur administration was continued thereafter throughout the rest of the study (6 wks). Body weight was recorded weekly. Renal function was evaluated by measuring the $24 \mathrm{~h}$. urine output, the concentrations of plasma creatinine, blood urea nitrogen (BUN) and creatinine clearance. Also, kidney weight and the parameters of oxidative stress: reduced glutathione (GSH), thiobarbituric acid reacting substance (TBARS) and the activities of superoxide dismutase (SOD), catalase and glutathione peroxidase (GPX) were measured in kidney tissue.

Results: The Kidney weight, plasma creatinine, BUN and $24 \mathrm{~h}$ urine output were significantly increased while the body weight and creatinine clearance were significantly decreased ( $\mathrm{P}<0.0005)$, in rats treated with Gen. as compared to control. While Cur. could significantly normalize the previous parameters. In addition Gen. caused oxidative stress in kidney as seen by significant increase in TBARS level, and significant decrease of catalase, GSH, SOD and GPX activities $(\mathrm{P}<0.0005)$, However, Cur. could normalize all the above parameters as compared to control.

Conclusion: Our data indicate that Cur. could suppress renal toxicity by blocking oxidative injury in the kidney and restore the antioxidant enzymatic profile. The renoprotective effect of Cur. is also evident by a remarkable improvement of renal function in Gen. injected rats. So Cur. can be used as a potent protective agent against renal oxidative damage mediated by Gen.
\end{abstract}

\section{Introduction}

Curcumin (Cur.) is a major yellow pigment in turmeric which is widely used as a spice and coloring agent in several foods. Curcuminoids are responsible for the yellow color of turmeric, as well as the yellow color of curry (Tirkey et al., 2005).

Curcuminoids are derived from turmeric by extraction with ethanol. Cur. Is the most studied form of the curcuminoids.
In its pure form,Cur. is a crystalline powder that is insoluble in water. It is also known as diferuloylmethane and turmeric yellow. Its chemical name is $(E, E)-1,7$ bis (4-hydroxy-3-methoxyphenyl)-1,6heptadiene-3, 5 dione. The molecular formula of Cur. is $\mathrm{C}_{21} \mathrm{H}_{20} \mathrm{O}_{6}$, its molecular weight is 368.39 daltons, and its structural formula is: 
<smiles>COc1cc(/C=C/C(=O)CC(=O)/C=C/c2ccc(O)c(OC)c2)ccc1O</smiles>

Cur. structure (Quoted from Chen et al.,2005)

Cur. and the other curcuminoids have been found to have antioxidant and antiinflammatory activities and have been entered into Phase I clinical trials for cancer chemoprevention by the National Cancer Institute (Ruby et al.,2005).

Cur. is currently attracting strong attention due to its antioxidant activities in vivo and in vitro lipid peroxidation system. It decreases hydrogen peroxide production and reduces the oxidized DNA formation in mo-use epidermis (Balasubramany et al., 2003).

It is well documented that Cur. scavenges superoxide anions, peroxynitrite radicals and singlet oxygen, also it is an inhibitor of neutrophil responses and superoxide generation in macrophages (Biswas et al., 2005).

Gentamicin (Gen.) is an antibiotic that is widely used against serious and lifethreatening gram-negative bacterial infection. However, its clinical use is limited due to its nephrotoxicity. Oxidative stress and nitrosative stress are reported to play an important role in Gen. nephrotoxicity (Dhanarajan et al, 2006).

Gen. nephrotoxicity accounts $10-15 \%$ of all cases of acute renal failure. The cells of the proximal renal tubules have the ability to concentrate Gen. several folds more than plasma levels (Rincon et al., 2004).

Gen. binds to the phospholipids of the cell membrane of the renal tubules and enter inside the cells, then it binds to subcellular organelles, alter the mitochondrial respiration, and small amount may be taken up by lysosomes (Erdem et al., 2000).

The aim of this study is to investigate the possible protective effect, and to elucidate the mechanism of action of Cur. on Gen.-induced renal dysfunction, in order to gain new insights into the prophylaxis of Gen. nephrotoxicity which is a common problem limiting the use of this drug.

\section{Material and Methods}

A total of 32 male albino rats weighing 210-230 gm. were used in this study. They were purchased from Hellowan Breeding Farm, and left in our laboratory for 2 week before beginning the experiment for acclimatization, then they were randomly assigned to the following 4 equal groups (i.e each $=8$ rats).

Group I : (control group): they were injected I.p with $1 \mathrm{cc}$ isotonic saline solution/day for 8 weeks.

Group II: (Cur. group ): they received Cur. $200 \mathrm{mg} / \mathrm{kg} / \mathrm{day}$ for 8 weeks, suspended in saline orally by means of gastric gavage tube (Tirky et al., 2005).

Group III: (Gen. group): they were injected I.p by Gen. (100 $\mathrm{mg} / \mathrm{kg} / \mathrm{day}$ ) for 8 days followed by $1 \mathrm{cc}$ normal saline I.p thereafter (i.e for 7 weeks) (Venkatesan et al., 2000).

Group IV: (Cur./Gen. group) : they received Cur. orally in the same dose as group II, for 8 week. While Gen. was injected I.p in a dose of $100 \mathrm{mg} / \mathrm{kg} / \mathrm{day}$ from the $8^{\text {th }}$ day of the experiment, for 8 days.

\section{Urine collection}

One day before sacrifice, each rat was kept individually in metabolic cage for $24 \mathrm{~h}$ urine collection. Urine was centrifuged at $1000 \mathrm{rpm}$ for $10 \mathrm{~min}$. to remove cells and debris, then dialyzed against phosphatebuffered saline $\mathrm{pH} 7.4$, and stored at $-70^{\circ} \mathrm{C}$ until investigation.

\section{Blood sampling}

At the end of the experiment, rats were sacrificed by decapitation under light ether anesthesia and the blood was collected from carotid artery into EDTA containing test tubes, then plasma was 
separated by centrifugation at $3000 \mathrm{rpm}$ for $15 \mathrm{~min}$. then stored at $-70^{\circ} \mathrm{C}$ until analysis.

\section{Biochemical analysis}

- Blood urea nitrogen (BUN) was measured according to Chancy and Marbach, (1962).

- Plasma and urine creatinine were determined according to Cook (1971).

- Creatinine clearance was calculated by the standard equation and was expressed as $\mathrm{ml} / \mathrm{min} / 100 \mathrm{~g}$ body weight.

\section{Kidney enzymes studies}

After sacrifice, the left kidney of each animal was immediately excised through midline abdominal incision and weighed then kept frozen at $-70^{\circ} \mathrm{C}$ for enzymatic analysis. Kidneys were perfused with ice cold saline $(0.9 \% \mathrm{Nacl})$ then homogenized in chilled $\mathrm{Kcl}(1.17 \%)$ using homogenizer. The homogen-ates were centrifuged at 800 rpm for $5 \mathrm{~min}$. at $4^{\circ} \mathrm{C}$ to separate the nuclear debris. Then the supernatant obtained was centrifuged at $10,500 \mathrm{~g}$ for 20 min. at $4^{\circ} \mathrm{C}$ to obtain post mitochondrial supernatants which were used to assay the enzymatic activity.

- The activity of superoxide dismutase (SOD) was assayed by the method of Kono (1978).

- Catalase activity was assayed by the method of Cliborne (1985).

- Reduced glutathione (GSH) was assayed by the method of Jollow et al. (1974).

- Glutathione peroxidase (GPX) activity was determined by the method described by Beutler (1971).

- Estimation of lipid peroxidation in kidney tissue : This was assessed by estimation of the thiobarbituric acid reacting substances (TBARS) level by the method of Ohkawa et al.(1979).

\section{Statistical analysis}

Results were expressed as mean \pm SEM. The intergroups variation was measured by one way analysis of variance (ANOVA) followed by Fischer's LSD test. Statistical significance was considered at $\mathrm{P}<0.05$. The statistical analysis was done using the Jandel Sigma Stat statistical Software version 2.0.

\section{Results}

Table (1) and Fig. (1) demonstrated the effect of Cur. administration on body weight, kidney weight, $24 \mathrm{~h}$ urine output, plasma creatinine, creatinine clearance and BUN in normal and Gen.-injected rats. Gen. treatment significantly reduced body weight and creatinine clearance $(\mathrm{P}<0.0005)$, and signific-antly increased the kidney weight, $24 \mathrm{~h}$. urine volume, plasma creatinine and BUN levels $(\mathrm{P}<0.0005)$, as compared to control group. Concurrent administration of Cur. with Gen., then continuation of Cur., could normalize all parameters. However Cur. per se had no significant effect on these parameters.

Table (2) and Fig.(2) demonstrated the effect of Cur. on the lipid peroxidation repre-sented by TBARS; and antioxidant enzymes in kidney tissue of normal and Gen. injected rats. Gen. injection significantly elevated TBARS and significantly decreased GSH, SOD, catalase and GPX $(\mathrm{P}<0.0005)$ as compared to control group. While administ-ration of Cur. could significantly reduce the TBARS and significantly elevate the antioxi-dant enzymes activity $(\mathrm{P}<0.0005)$ towards normal. On the other hand, Cur. per se did not affect any of these parameters than normal. 
Table (1): Effect of curcumin on body weight, kidney weight and renal function of normal and gentamicin- injected male rats $(n=8)$.

\begin{tabular}{|l|c|c|c|c|}
\hline Variables & Control & Cur. & Gen. & Gen./Cur. \\
\hline Body weight changes (gm) & $42.5 \pm 2.1$ & $49.8 \pm 2.3$ & $-11.3 \pm 1.2$ & $15.8 \pm 1.42$ \\
& & $\mathrm{P}>0.05$ & $\mathrm{P}<0.0005^{\mathrm{ab}}$ & $\mathrm{P}<0.0005^{\mathrm{bc}}$ \\
\hline Kidney weight (gm) & $2.8 \pm 0.21$ & $3.0 \pm 0.31$ & $6.1 \pm 0.28$ & $3.2 \pm 0.31$ \\
& & $\mathrm{P}>0.05$ & $\mathrm{P}<0.0005^{\mathrm{ab}}$ & $\mathrm{P}<0.0005^{\mathrm{c}}$ \\
\hline 24 h. urine output (ml) & $4.8 \pm 0.66$ & $5.1 \pm 0.66$ & $13.8 \pm 1.7$ & $6.2 \pm 1.37$ \\
& & $\mathrm{P}>0.05$ & $\mathrm{P}<0.0005^{\mathrm{ab}}$ & $\mathrm{P}<0.0005^{\mathrm{c}}$ \\
\hline Plasma Creatinine (mg/dl) & $0.97 \pm 0.05$ & $0.95 \pm 0.04$ & $3.51 \pm 0.13$ & $1.2 \pm 0.11$ \\
& & $\mathrm{P}>0.05$ & $\mathrm{P}<0.0005^{\mathrm{ab}}$ & $\mathrm{P}<0.0005^{\mathrm{c}}$ \\
\hline Creatinine clearance & $0.78 \pm 0.05$ & $0.79 \pm 0.03$ & $0.085 \pm 0.01$ & $0.82 \pm 0.04$ \\
(ml/min) & & $\mathrm{P}>0.05$ & $\mathrm{P}<0.0005^{\mathrm{ab}}$ & $\mathrm{P}<0.0005^{\mathrm{c}}$ \\
\hline BUN (mg/d) & $25.21 \pm 0.85$ & $27.12 \pm 0.35$ & $75.82 \pm 2.8$ & $29.32 \pm 1.8$ \\
& & $\mathrm{P}>0.05$ & $\mathrm{P}<0.0005^{\mathrm{ab}}$ & $\mathrm{P}<0.0005^{\mathrm{c}}$ \\
\hline
\end{tabular}

$\mathrm{n}=$ number of rats in each group.

Values are expressed as mean \pm SEM; $\mathrm{P}<0.05$ is considered significant.

a. Values significantly different as compared to control group.

b. Values significantly different as compared to Cur. group.

c. Values significantly different as compared to Gen. group.

Table (2): Effect of curcumin on TBARS and the antioxidant activity in kidney tissue of normal and gentamicin -injected male rat $(n=8)$.

\begin{tabular}{|l|c|c|c|c|}
\hline Variables & Control & Cur. & Gen. & Gen./Cur. \\
\hline TBARS & $44.7 \pm 2.1$ & $46.5 \pm 2.2$ & $122 \pm 4.2$ & $54.2 \pm 2.8$ \\
(n mol/mg protein) & & $\mathrm{P}>0.05$ & $\mathrm{P}<0.0005^{\mathrm{ab}}$ & $\mathrm{P}<0.0005^{\mathrm{abc}}$ \\
\hline GSH & $31.2 \pm 1.8$ & $34.0 \pm 2.2$ & $9.7 \pm 1.1$ & $28.8 \pm 2.1$ \\
(m mol/mg protein) & & $\mathrm{P}>0.05$ & $\mathrm{P}<0.0005^{\mathrm{ab}}$ & $\mathrm{P}<0.0005^{\mathrm{bc}}$ \\
\hline SOD & $16.3 \pm 1.5$ & $19.1 \pm 1.8$ & $3.8 \pm 0.21$ & $14.8 \pm 1.2$ \\
(U/mg protein) & & $\mathrm{P}>0.05$ & $\mathrm{P}<0.0005^{\mathrm{ab}}$ & $\mathrm{P}<0.0005^{\mathrm{bc}}$ \\
\hline Catalase (K/min) & $1.7 \pm 0.09$ & $1.9 \pm 0.08$ & $0.3 \pm 0.02$ & $1.85 \pm 0.08$ \\
& & $\mathrm{P}>0.05$ & $\mathrm{P}<0.0005^{\mathrm{ab}}$ & $\mathrm{P}<0.0005^{\mathrm{c}}$ \\
\hline GPX & $3.4 \pm 0.31$ & $3.8 \pm 0.12$ & $1.6 \pm 0.11$ & $3.1 \pm 0.28$ \\
(U/g wet tissue) & & $\mathrm{P}>0.05$ & $\mathrm{P}<0.0005^{\mathrm{ab}}$ & $\mathrm{P}<0.0005^{\mathrm{bc}}$ \\
\hline
\end{tabular}

$\mathrm{n}=$ number of rats in each group.

Values are expressed as mean \pm SEM; $\mathrm{P}<0.05$ is considered significant.

(a) Values significantly different as compared to control group.

(b) Values significantly different as compared to Cur. group.

(c) Values significantly different as compared to Gen. group. 
The Protective Effect of Curcumin Against Gentamicin-Induced...........

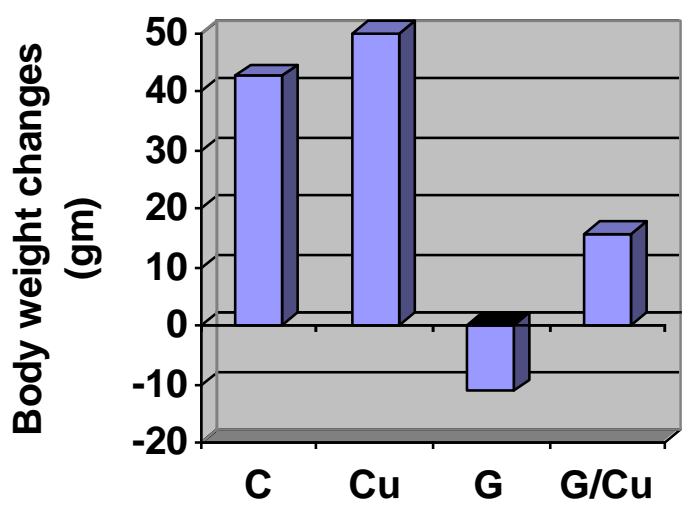

(a)

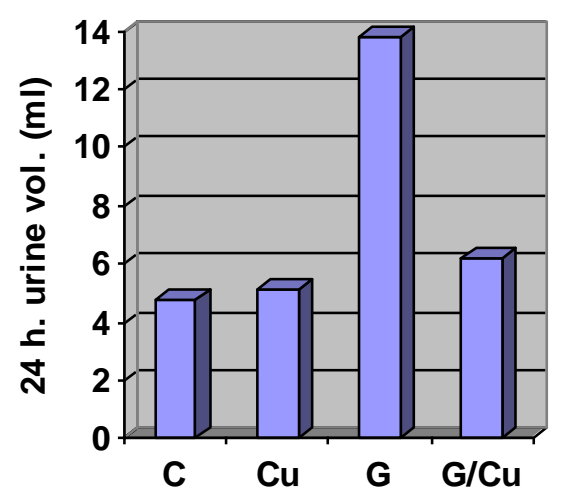

(c)

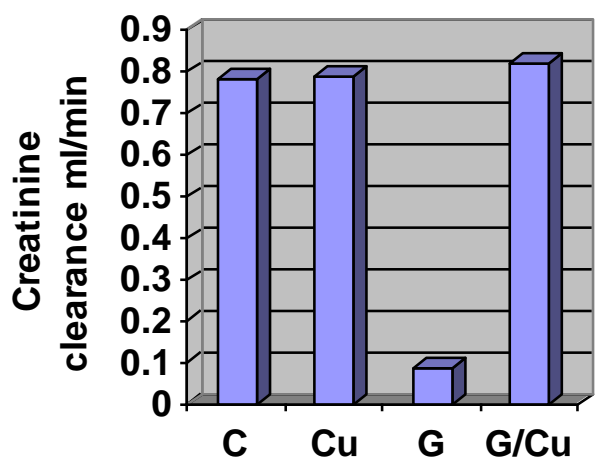

(e)

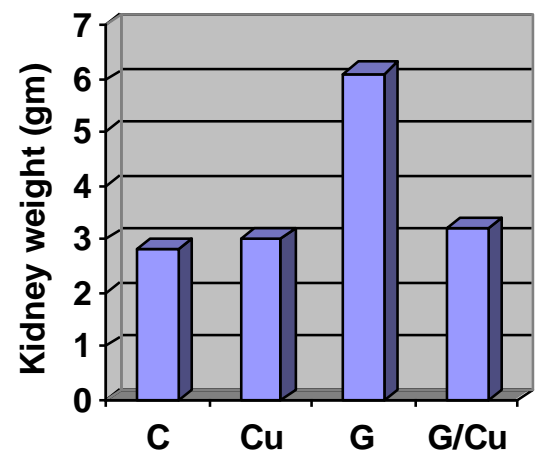

(b)



(d)

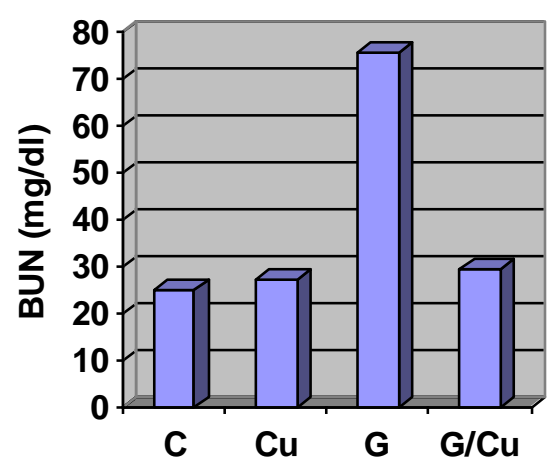

(f) 
Fig.(1): The effect of curumin administration on (a) body weight, (b) kidney weight, (c) 24 $h$ urine output, (d) plasma creatinine, (e) creatinine clearance and (f) BUN, in normal and gentamicin-injected male rats.

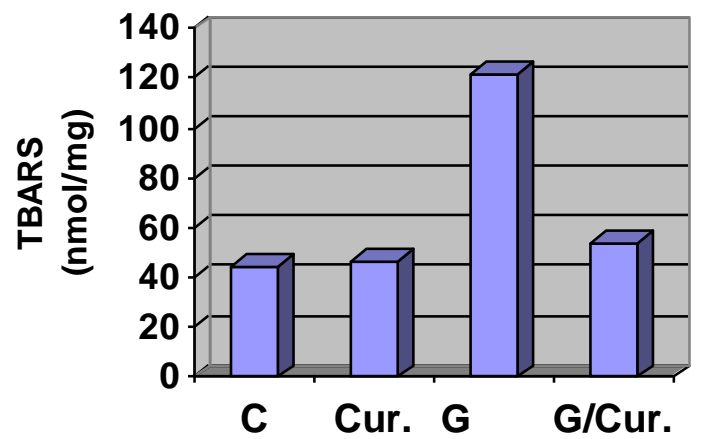

(a)

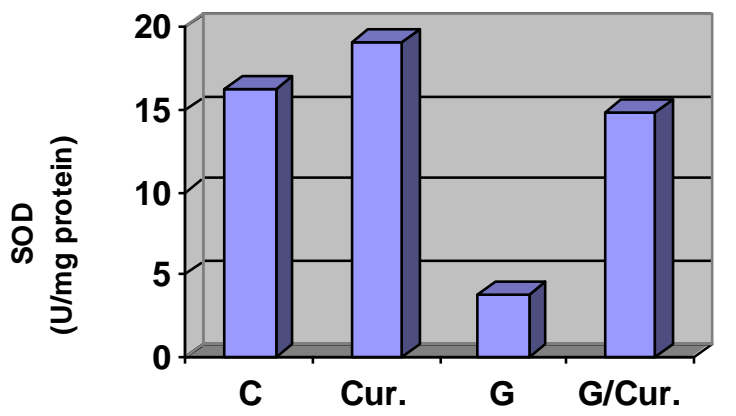

(c)

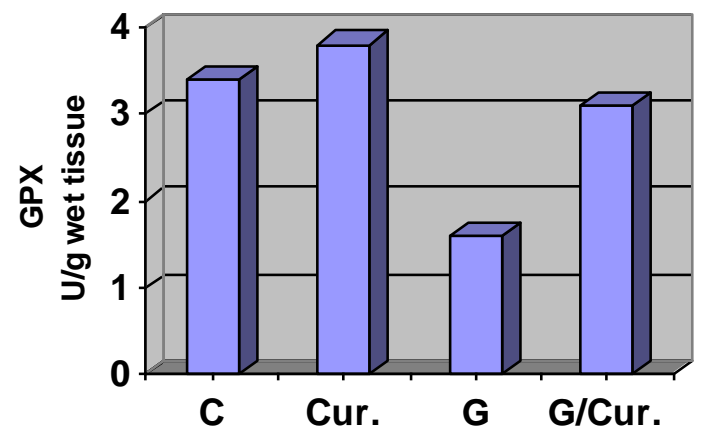

(e)

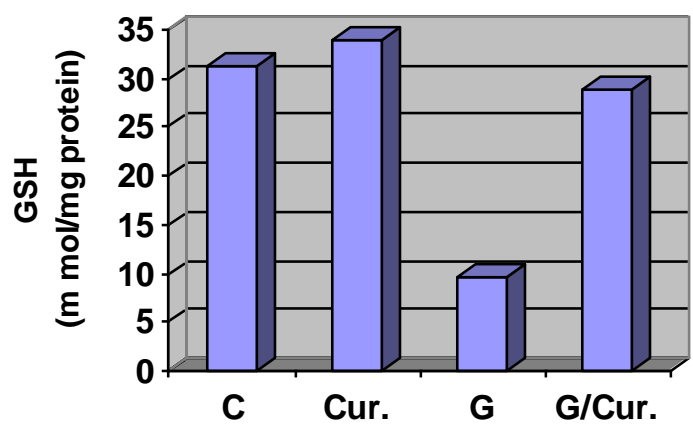

(b)

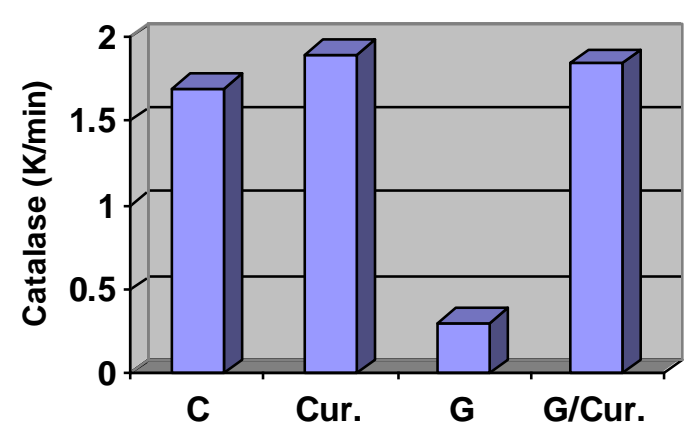

(d) 
(Fig 2): Effect of curcumin on (a) TBARS ,(b)GSH,(c) SOD, (d) Catalase and (e) GPX, in kidney tissue of normal and gentamicin-injected male rats.

\section{Discussion}

Curcumin (Cur.) is a natural herb commonly used as an anti-inflammatory, anticancer and recently discovered its antioxidant potential (Somasundaram et al.,2002 and Chen et al.,2005).

Gentamicin (Gen.) is an antibiotic that is widely used against serious gramnegative infection. However its clinical use is limited by its nephrotoxicity. Oxidative stress is reported to play important role in Gen. nephrotoxicity (Dhanarajan et al.,2006). The aim of this work was to study the possible protective and antioxidant effects of Cur. in renal dysfunction mediated by Gen. treatment in male rats

Our results revealed that Gen. injection resulted in decrease in the body weight and increase in kidney weight, while Cur. administration could normalize these changes. It has been reported by Erdem et al. (2000) that Gen. causes loss of appetite, together with the increased catabolism, seen in Gen.-induced acute renal failure, results in acidosis which is accompanied by anorexia. Hence oral food intake decreases and this may cause body weight loss.

The observed improvement of body weight by Cur. may be due to increase the appetite by Cur., as the appetizer effect of Cur. is well documented (Ammon and Wahl, 2001). This together with the antiinflammatory and the antioxidant effects of Cur., that probably prevent the toxic effect of Gen. (Balasabramany et al., 2003), may be responsible for body weight improvement.

The increase in the kidney weight by Gen. probably resulted from oedema that is caused by drug-induced acute tubular necrosis. This was confirmed histopathologically in the study of Erdem et al (2000) in which the electron microscopy examination revealed mitochondrial swelling and cytoplasmic degeneration together with accumulation of myeloid bodies in kidney tissues of Gen.-treated rats.
It has been reported that binding of Gen. to biological membranes is affected by several factors. For example, ischemia enhances this binding, while $\mathrm{ca}^{2+}$ inhibits it competitively (Dhanarajan et al, 2006). In addition Gen. interacts with the subcellular membranes and structures such as mitochondria, lysosomes and microsomes. Gen. also affects membrane fluidity, however, the mechanism of this effect is still unclear (Rincon et al.,2004).

On the other hand it has been suggested that Cur. stabilizes the cell membrane by altering the membranes cation-binding characteristics (Venkatesan et al., 2000). Cur. has been found to inhibit reactive oxygen species (ROS) production and $\mathrm{Ca}^{2+}$ entry. The likely mechanisms are: (i) Cur. apart from its effects on sarcoendoplasmic reticulum $\mathrm{Ca}^{+2}$ ATP ase (SERCA), may also inhibit inositoltriphosphate (IP3) - sensitive $\mathrm{Ca}^{2+}$ channel (Dyer et al., 2002) and thereby breaks the coupling of IP3-sensitive $\mathrm{Ca}^{2+}$ store and $\mathrm{Ca}^{2+}$ entry and (ii) Cur. may inhibit cytosolic signals (enzymes or other signaling molec-ules) that are responsible for $\mathrm{Ca}^{2+}$ entry into the cells (Balasubramany et al., 2003).In addition, Cur. might play a critical role in suppressing ROS mediated destruction of basement membrane and proteinuria (Venkatesan et al., 2000).

The present study revealed that injection of Gen. to rats for 8 days caused marked impairment of renal function as it resulted in significant decrease in creatinine clearance and significant increase in plasma creatinine, BUN and the $24 \mathrm{~h}$ urine volume versus control, that indicated the presence of Gen.-induced polyuria. Whereas combination of Cur. with Gen. could improve all renal function parameters and became not different from that of control pointing out the protective role of Cur. against acute tubular necrosis.

Several studies reported the nephrotoxic effect of Gen. by increasing 
apoptosis leading to acute tubular necrosis and acute renal failure in $10-15 \%$ of all cases (Rincon et al., 2004; Pedreanez et al., 2004 and Jovanovic et al., 2005).

Cur. has been shown to significantly and dose dependently improve the renal dysfunction induced by cyclosporine-in rat kidney, as it improved creatinine clearance and decreased the elevated levels of serum creatinine and BUN (Tirkey et al., 2005). Earlier studies have also shown that Cur. pretreatment decreases ischemiareperfusion induced rise in serum creatinine levels in kidney (Shoskes, 1998). Venkatesan et al., (2000) confirmed the protective effect of Cur. against nephrotexicity. They suggested that the antioxidant, anti-inflammatory membrane stabilizing and hypolipidemic properties of Cur. may constitute an important part of its therapeutic effects. They also observed that Cur. treatment was accompanied by significant reduction in urinary excretion of glycosaminoglycan in adriamycin-induced nephrosis. This suggested that Cur. may influence the integrity of the glomerular basement membrane. Because the basement membrane is subject to damage in adriamycin nephrosis (Rincon et al., 2004). In addition Cur. treatment has been found to retard the abnormal passage of high molecular weight macromolecules from the blood to the urinary space (Venkatesan et al., 2000).

In the present study Gen. produced oxidative stress and increased the lipid peroxidation in kidneys as reflected by the elevated renal TBARS levels with significant decrease of all antioxidant enzymes namely GSH, SOD, catalase and GPX. However the pretreatment and administration of Cur. for 8 weeks could effectively reverse and normalize this figure.

Gen. administration to rats has been found to enhance the production of $\mathrm{H}_{2} \mathrm{O}_{2}$ in renal cortical mitochondria, as a result of the increase in the production of superoxide anions(Walker and Shah,1999). Superoxide anion and $\mathrm{H}_{2} \mathrm{O}_{2}$ may interact to form a reactive and unstable radical, namely a hydroxyl radical. This radical is formed by the reaction between $\mathrm{H}_{2} \mathrm{O}_{2}$ and $\mathrm{Fe}^{2+}$ (Shah and Walker, 2002). Thus, $\mathrm{Fe}^{2+}$ appears to play an important role in the production of reactive oxygen radicals in Gen. nephrotoxicity. When oxygen radicals begin to accumulate, renal cells exhibit a defensive mechanism by using various antioxidant enzymes; such as catalase, SOD and Gpx. Reduced activity of one or more antioxidant systems, due to the direct toxic effect of Gen. or volume depletion due to Gen. Administr-ation, leads to an increase in lipid peroxid-ation. The decreased amount of intracellular glutathione, and the accumulation of $\mathrm{H}_{2} \mathrm{O}_{2}$ and hydroxyl radicals are the triggering factors in Gen. nephrotoxicity. The decrease in the amount of intracellular glutathione results in the inhibition of Gpx that is known to take part in the inactivation of $\mathrm{H}_{2} \mathrm{O}_{2}$. This process leads to a vicious circle which makes the prognosis more severe (Obatomi and Plummer,2003).

Cur. has been shown to decrease lipid peroxidation possibly by its antioxidant mechanism. Oxidative stress can promote the formation of a variety of vasoactive media-tors that can affect renal function directly by causing renal vasoconstriction or decreasing the glomerular capillary ultrafiltration coefficient; and thus reducing glomerular filtration rate (Pari and Murugan, 2006). Thus the attenuation of lipid peroxidation in Gen.-treated rats by Cur. provides a convincing evidence for the involvement of ROS in Gen. -induced lipid peroxidation. Rukkumani et al.,2003 reported the protective effect of Cur. on circulating lipids in plasma and lipid peroxidation products in alcohol and polyunsaturated fatty acid-induced toxicity.In addition in-vitro findings support the hypothesis that Cur. inhibits free radical induced apoptosis in cell lines( Somasundaram et al.,2002). Pari and Murugan (2007), claimed that the Cur. inhibit ironcatalyzed lipid peroxidation in rat brain tissue homogenates by chelation of iron.

Our study is in agreement with the study of Venkatesan et al. (2000) who reported that Cur. suppressed adriamycininduced lipid peroxidation in kidney microsomes and mitochondria in a dosedependent manner. Also, they reported that Cur. treatment increased the glutathione content and glutathione peroxidase activity of kidney tissues in adriamycin injected rats. This increase in both the nonenzymatic and enzymatic antioxidants may play 
significant role in the mechanism of the protective effect of Cur. (Pari and Murugan, 2006). Cur. has been shown to inhibit hydrogen peroxide induced oxidative injury in a renal cell line (Farombi and Ekor, 2006). Cur. is also protective against adriamycin cardiac injury (Venkatesan, 1998). These findings support that Cur. suppresses oxidative injury in a wide variety of tissues including heart and kidney.

Several studies reported the ability of Cur. to mainly eliminate the hydroxyl radical, superoxide radical, singlet oxygen, nitrogen dioxide and $\mathrm{NO}$ (Sreejayan and Rao,1997; Ruby et al., 2005 and Sharma et al., 2006). Vajragupta et al. (2003) have reported that Cur. manganese complex and acetylcurc-umin- manganese complex, low molecular weight synthetic compounds, showed much greater SOD activity and an inhibitory effect on lipid peroxidation. Priyadarsini et al. (2003) have shown, in vitro, that the origin of the antioxidant activity of Cur. is mainly from the phenolic $\mathrm{OH}$ group, although a small fraction may be due to the $\mathrm{CH}_{2}$ site.

Reduced glutathione (GSH), a major nonprotein thiol in living organisms, plays a crucial role in coordinating the body's antioxidant defense processes. Results in the present study indicated that Gen. administration drastically lowered the levels of GSH in the kidney. Improvement of renal GSH levels in Cur. treated rats in comparison to Gen. administered rats further demonstrates the antioxidative effect of Cur. Cur. has been shown to increase the levels of glutathione reductase in ischemic brains of rats as well as alveolar and human leukemia cell (Thiyagarajan and Sharma, 2004) . In addition, it has been shown that chronic treatment by Cur. also improved the levels of two key antioxidant enzymes SOD and catalase in puromicin administered rats (Farombi and Ekor, 2006).

\section{Conclusion}

The present study demonstrated that Cur. could suppress renal oxidative stress by blocking oxidative injury, as it prevented Gen.-induced rise in lipid peroxidation represented by TBARS and restoration of the antioxidant enzymatic profile. The renopro-tective effect of Cur. is also evident by a remarkable improvement of renal function as judged by restoration of creatinine clearance, creatinine and BUN levels in Gen. injected rats. So Cur. can be used in prophylaxis and to block Gen. nephrosis.

\section{References}

1. Ammon $P$ and Wahl A (2001): Pharmacology of Curcuma longa. Planta. Med., 57:1-7.

2. Balasubramany U, Koteswari A, Kumar S, (2003): Curcumin induced inhibition of cellular reactive oxygen species generation: novel therapeutic implications. J. Biosc., 28:715-21.

3. Beutler E (1971): Determination of glutathione peroxidase. Annu. Biochem. Methods., 3: 66-8.

4. Biswas S, Moclure $D$ and Jimenez A, (2005): Curcumin induces glutathione bios-ynthesis and inhibits NF. Kappa B activation and interleukin 8 release. Antioxid. Redox. Signal., 7: 32-41.

5. Chancy $\mathbf{L}$ and Marbach $\mathbf{P}$ (1962): Modified reagents for determination of urea and ammonia. Clin. Chem., 8:130-2.

6. Chen J, Wanming D, Zhang D, Liu Q and Kang J (2005): Watersoluble antioxidants improve the antioxidant and anticancer activity of low concentrations of curcumin in human leukemia cells. Pharmazie., 60:57-61.

7. Claiborne, A (1985): Handbook of Methods for Oxygen Radical Reaserch. Boca Raton FL., editor CRC Press. p 283-4.

8. Cook J (1971): Assessment of creatinine. Clin. Chem. Acta., 32,485-9.

9. Dhanarajan R, Abraham $\mathbf{P}$ and Isaac B (2006): Protective Effect of Ebselen drug, against gentamicin-induced renal damage in Rats, Basic. Clin. Pharmacol. Toxicol., 99(3), 267-72.

10. Dyer J , Khan S , Bilmen J , Hawtin $S$ and Javed $U$ (2002): Curcumin a new cell perm-eant 
inhibitor of the inositol 1,4,5trisph-osphate receptor; Cell Calcium, 31: 45-52.

11. Erdem A, Gundogan N, Alp U, and Kara A (2000): The protective effect of taurine against Gen.-induced acute tubular necrosis in rats.Nephrol Dial.Transplant, 15:1175-82.

12. Farombi E and Ekor M, (2006): Curcumin attenuated puromycininduced renal oxidative damage in rats. Food Chem. Toxicol., 44 (9) : 1443-8.

13. Jovanovic D., Jovovic D., Mihailovic N. and Maksic N. (2005): Influence of carvedilolon on chronic renal failure progression in spontaneously hypertensive rats with adriamycin nephropathy. Clin. Nephrol., 63(6)446-53.

14. Jollow D, Mitchell $L$ and Gillete J.

(1974): The protective role of glutathione and evidence for 3,4-bromobenzenoxide as the hepatotoxic intermediate. Pharmacol., 11:151-9.

15. Kono Y. (1978): Generation of superoxide radical during autoxidation of hydroxylamine and an assay for superoxide dismutase. Arch Biochem Biophys., 186: 189-95.

16. Obatomi K, Plummer T. (2003): Influence of hydration states on the acute nephrotoxic effect of gentamicin in the rat. Toxicol., 80: 141-52.

17. Ohkawa H, Ohishi N, Yagi K and Assay (1979): Assay for lipid peroxides in animal tissues by thiobarbituric acid reaction. Anal Biochem., 95: 351-358.

18. Pari L and Murugan P. (2006): Tetrahydrocurcumin effect on chloroquin-mediated oxidative damage in rat kidney. Basic. Clin. Pharmacol. Toxicol., 99 (5): 32934.

19. Pari L and Murugan P. (2007): Tetrahydrocurcumin prevents brain lipid peroxidation in streptozotocin-induced diabetic rats.J. Med. Food., 10(2):323-9.

20. Pedreanez A., Rincon J., Romero M. and Viera N. (2004):
Melatonin decreases apoptosis and expression of apoptosisassociated proteins in acute puromycin aminonucleoside nephrosis. Nephrol. Dial Transplant., 19(5): 1098-105.

21. Priyadarsini I, Naik $\mathbf{H}$, Satav J and Mohan $H$ (2003): Role of phenolic $\mathrm{OH}$ and methylene hydrogen on the free radical reactions and antioxidant activity of curcumin.Free Radic. Biol Med., 35:475-84.

22. Rincon J, Romero $M$, Viera $\mathbf{N}$, Pedreanea $A$ and Mosquera $J$. (2004): Increased oxidative stress and apoptosis in acute puromycin aminonucleoside nephrosis. Int. J. Exp. Pathol., 85(1): 25-33.

23. Ruby AJ, Kuttan G, Babu KD and Kuttan R (2005): Antitumour and antioxidant activity of natural curcuminoids. Cancer. Lett., 94:79-83.

24. Rukkumani R, Sri M. and Menon P. (2003): Protective effects of photoirradiated curcumin on circulatory lipids and lipids peroxidation products in alcohol and polyunsaturated fatty acid-induced toxicity. Phytother. Res., 17: 925-9.

25. Shah V, and Walker D (2002): Reactive oxygen metabolites in toxic acute renal failure. Renal Fail., 14: 363-70.

26. Sharmas S, Kulkarn $K$ and Chopra K (2006): Curcumin the active principle of turmeric (Curcuma longata), ameliorates diabetic nephropathy in rats. Clin. Exp. Pharmacol. Physiol., 33(10):940-5.

27. Shoskes A (1998): Effect of bioflavonoids quercetin and curcumin on ischemic renal injury: a new class of renoprotective agents. Transplant., 66:147-52.

28. Somasundaram S, Edmund A, Moore D, Small $G$ and Shi $Y$ (2002): Dietary curcumin inhibits chemotherapy-induced apoptosis in models of human breast cancer. Cancer Res., 62: 3868-75.

29. Sreejayan I,and Rao N (1997): Nitric oxide scavenging by curcuminoids. J. Pharm. Pharmacol., 49:105-7.

30. Thiyagarajan $\mathbf{M}$ and Sharma $\mathbf{S}$ (2004): Neuroprotective effect of 
curcumin in middle cerebral artery occlusion induced focal cerebral ischemia in rats. Life Sci., 74:969985.

31. Tirkey N, Kaur G, Vij G, and Chopra K. (2005): Curcumin a diferuloylmethane, attenuates cyclosporine induced renal dysfunction and oxidative stress in rat kidneys. J. Biosc., 22 (2) 23346.

32. Vajragupta $\mathbf{O}$, Watanabe $\mathbf{H}$, Tohda $M$ and Sumanont Y(2003) Manganese complexes of curcumin and its derivatives: evaluation for the radical scavenging ability and neuroprotective activity. Free Radio. Biol. Med., 35:1632-44.

33. Venkatesan N (1998): Curcumin attenua-tion of acute adriamycin myocardial toxic-ity in rats. Br. J. Pharmcol., 124, 425-27.

34. Venkatesan N, Durairaj $P$ and Arumugam (2000): Curcumin prevents adriamycin nephrotoxicity in rats. $\mathrm{Br}$. $\mathrm{J}$. Pharmacol., 129, 231-4.

35. Walker D and Shah V (1999): Evidence suggesting a role for hydroxyl radical in Gen.-induced acute renal failure in rats. J. Clin. Invest., 81: 334-41.

\section{التأثير الواقي للكركم ضد الخلل الوظيفي والتأكسد بكلى ذكور الفئران البيضاء المحدث بعقار الجنتاميسين

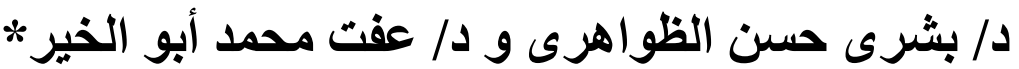

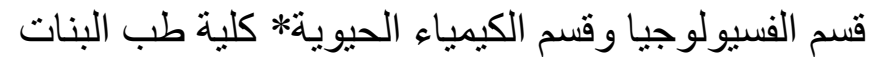

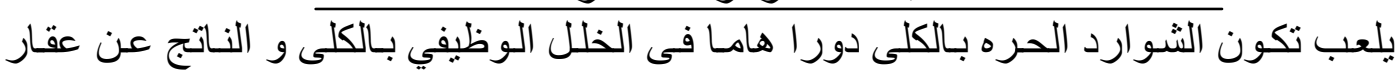



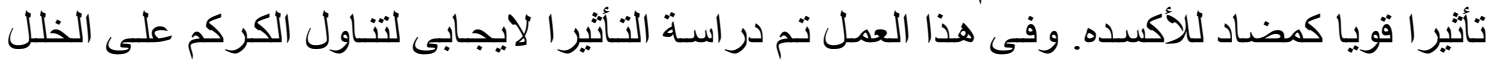

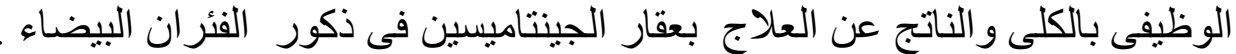
متساوية:ة المجمو عة الأولى (الضابطة) تم حقنها بـ 1سم محلول ملح طبيعى بالغشاء البريتونى يوميا لمدة 8 أسابيع. المجمو عة الثنانية: تم إعطاءهـا كركم 200مجم/كجم يوميا لمدة 8 أسـابيع بالفم- معلقة فى محلول المجموعة الثالثة: تم حقنها بعقار الجينتاميسين (100 مجم/كجم/يوم) بالغشاء البريتونى لمدة 8 أيسام

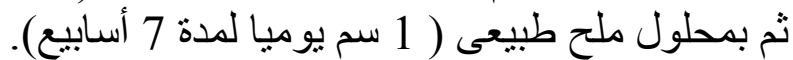

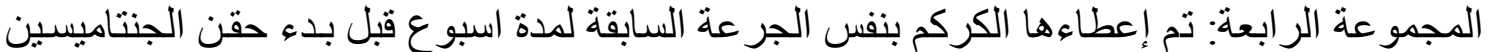
(الذى استمر لددة 8 أيام)وقد تم أثناء هذه الدمة تنتاول كل من الكركم و الجيناميسين ثم إستمر تنتاول

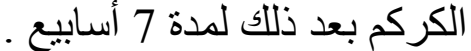
وقد تم وزن جسم الفئران اسبو عيا. كما تم تحديد وظائف الكلى عن طريق تحئ تحديد كميـة بول 24

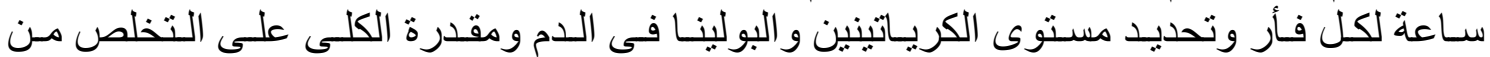

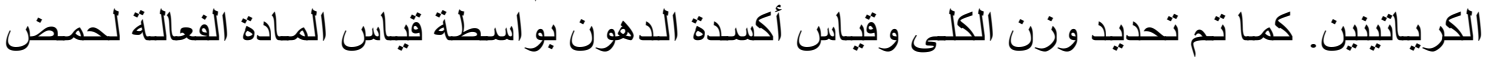


الثيوباربيتوريك و الجلوتاثيون المختزل بالاضـافه الى قياس نسبة نشـاط الإنزيمات المضـادة للأكسدة





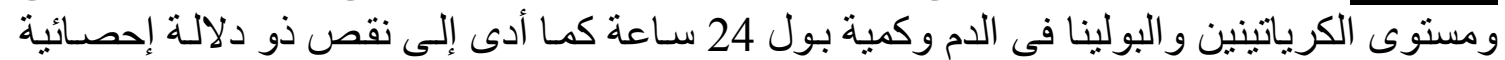

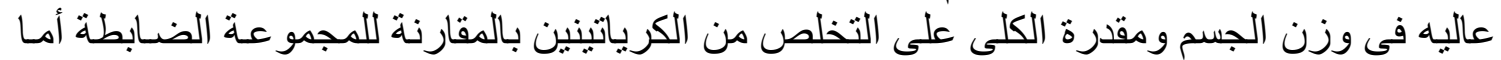

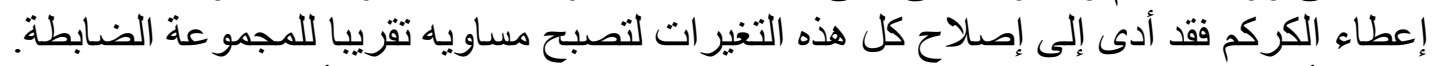

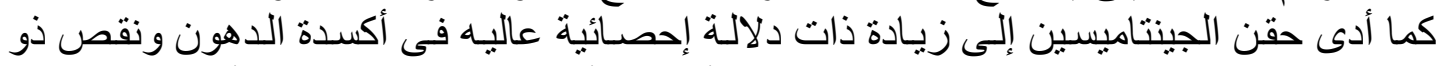

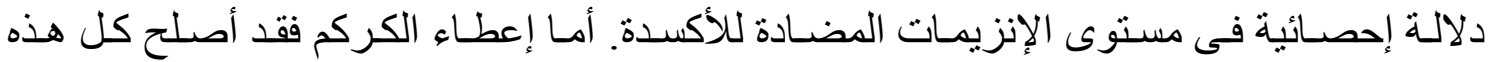
التغير ات لتصبح قريبه من مستويات الإنة المجمو عنة الضابطة.

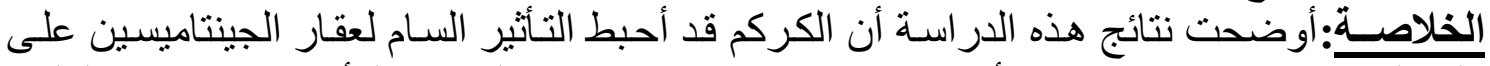

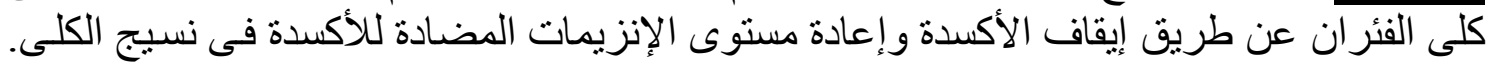



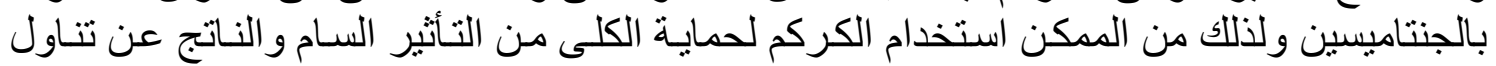
عقار الجينتاميسين. 